\title{
Occurrence of Aphidophagous Syrphids in Aphid Colonies on Cabbage (Brassica oleracea) and their Parasitoids
}

\author{
S. Mayadunnage, H.N.P Wijayagunasekara ${ }^{1}$, K.S. Hemachandra ${ }^{1}$ and L. Nugaliyadde ${ }^{2}$ \\ Postgraduate Institute of Agriculture \\ University of Peradeniya \\ Peradeniya, Sri Lanka
}

\begin{abstract}
Syrphid (Diptera: Syrphidae) larvae and pupae (149) were collected from an organically grown cabbage field maintained by Department of Agricultural Biology, Faculty of Agriculture, University of Peradeniya. Out of them 15 adults of syrphids emerged and were identified as Allograpta javania and Episyrphus viridaureus (Wiedemann). Most larvae died during rearing. Out of the remaining, $66.7 \%$ were parasitized. A significant correlation coefficient (0.83) between the mean number of cabbage aphids and syrphid larvae was noticed. Three species of hoverfly parasitoids, Diplazon orientalis (Cameron) and Diplazon laetatorius (F.) (Ichneumonidae) and Syrphophagus sp. (Encyrtidae) were reared. The Diplazon laetatorius is found to be a new record from Sri lanka. The most frequently found parasitoid was Diplazon laetatorius and the per cent parasitism was 50. The per cent parasitism of Diplazon orientalis and Syrphophagus sp. was 42.3 and 6.3 respectively. Morphological details of each parasitoid species is presented. A significant correlation coefficient (0.91) between total hoverfly larvae and the parasitized hoverfly larvae was noticed. At the beginning of observations, the number of the parasitized larvae was small. As the number of syrphid larvae feeding in cabbage aphid colonies was increasing, the percentage of parasitized larvae increased. During observations in a conventional cabbage field at Paingamuwa area in the Kandy District, 40 syrphid larvae and pupae were collected. Out of them, thirteen adults of syrphids emerged and were identified as Allograpta javania and Episyrphus viridaureus. Most larvae died during rearing. Out of the remaining $10.37 \%$ were parasitized. Total number of hoverfly larvae in the insecticide free vegetable field was more than four times higher than the conventionally managed field. Predators of aphids other than syrphids were found at the two sites in low numbers.
\end{abstract}

\footnotetext{
1 Department of Agricultural Biology, Faculty of Agriculture, University of Peradeniya, Peradeniya, Sri Lanka

2 Department of Agricultural Biology, Faculty of Agriculture, University of Ruhuna, Mapalana, Sri Lanka
} 


\section{INTRODUCTION}

The family Syrphidae comprises three subfamilies, 180 genera, and about 6,000 described species (Vockeroth and Thompson, 1987). The larvae of the subfamily Syrphinae commonly known as hoverfly larvae are considered as specialized aphidophagous predators distributed worldwide (Chambers et al., 1986; Vockeroth and Thompson, 1987). Although a considerable amount of research has been conducted on the biology and ecology of the coccinellids, the syrphids, as a group, have been somewhat neglected.

At least 49 species of Syrphidae attack green peach aphid, Myzus persicae (Sulzer) (Emden et al., 1969). De Silva (1961) reported several predatory hoverfly species (Ischiodon scutellaris, Syrphus transversua, Ascarina aegrota, Spaerophoria scutella) in Sri Lanka.

The adults feed mainly on pollen and nectar, or honeydew produced by aphids (Sobota and Twardowski, 2004). Hoverflies along with other aphidophagous insects play a very important role in the reduction of aphid populations (Sobota and Twardowski, 2004). Occurrence of syrphids is one of the most important factors decreasing the number of cabbage aphids, a main pest of cabbage vegetables (Wnuk, 1971; Wnuk and Fusch, 1977; Wnuk and Wojciechowicz, 1993).

Though larvae of the aphidophagous species of Syrphidae reduce natural populations of aphids no instance of a successful biological control through the employment of a syrphid alone has been reported so far. The limitation in the use of syrphid flies in biological control systems is associated with the problem of rearing the adults and the larvae which depend upon entirely different sources of food, as discussed by Schneider (1969).

Aphidophagous syrphids are attacked by a wide range of parasitoids commonly being in the families Ichneumonidae, Encyrtidae, Pteromalidae, Megasplidae and Figitidae (Scott, 1939). They reduce the number of syrphids and negatively affect their function in the control of aphid populations.

In Sri Lanka, predatory hoverflies are neglected and very few studies about them and their parasitoids have been conducted. Therefore, the aim of the study was to understand the population distribution of hoverfly larva with aphids and determine their role in the reduction of syrphid population associated with cabbage aphid colonies. In addition, parasitoids of hoverfly larvae were also examined.

\section{MATERIALS AND METHODS}

\section{Locations}

This investigation was carried out in two locations. Observations on cabbage aphids were taken at an insecticide free farm maintained by Department of Agricultural Biology, Faculty of Agriculture, University of Peradeniya (from June 2008 to September 2008) and at conventional cabbage field at Paingamuwa area in the Kandy District (from January 2009 to March 2009). In this field, continuous data regarding parasitoids of predatory hoverflies were also recorded. 


\section{Sampling methodology}

Syrphid larvae and pupae were collected from the cabbage aphid colonies feeding on Brassica oleracea. Forty cabbage plants of the same age were inspected for aphids and hoverfly larvae at weekly intervals during the study period. Counting of aphids on cabbage leaves was done according to the method described by Shukla (1990).

\section{Rearing and identification of syrphid predators}

All syrphids were reared separately in glass bottles in the laboratory until either parasitoid or host emergence. Larvae were fed on cabbage aphids. The emerged adults were identified to genera level using published literature (Ghorpade, 1994; Borror et al., 1989; Beibienko, 1988; Daniel and Drew, 1976; Weems, 1953). Parasitoids that emerged from some of the syrphid larvae and pupae were identified using published literature (Borror et al., 1989. Baltazar, 1964; Broad, 2006). The specimens were identified up to the species level by Dr. Kumar Ghorpadae, University of Agricultural Sciences, Krishi Nagar, Dharwar, India.

\section{Calculation of per cent parasitism}

The per cent parasitism of syrphid larvae was calculated using the following formula.

$$
\begin{aligned}
& \text { Parasitism } \%=\frac{\text { Number of hosts from which parasitoids emerged }}{\text { Number of hosts from which parasitoids emerged }+ \text { number of }} \times 100 \\
& \text { host adults emerged }
\end{aligned}
$$

\section{Data analysis}

Minitab statistical package and Excel was used to analysis the data. The observations were summarized in a frequency table, and dispersion indices such as mean, variance, and variance: mean ratio was calculated for each set of observations and a regression analysis were done whenever necessary.

\section{RESULTS AND DISCUSSION}

\section{Occurrence of predatory syrphids in organically grown cabbage}

During observations, 149 syrphid larvae and pupae were collected. Out of them, 15 adults of syrphids emerged and were identified as Allograpta javania and Episyrphus viridaureus. Most larvae died during rearing due to unknown reasons. However, out of the remaining larvae and pupae, $66.7 \%$ were found to be parasitized. Jankowska (2004) noted that most of syrphid larvae died during rearing and there were 30\% parasitized larvae among the remaining ones.

First syrphid larvae were noted two weeks after first appearance of aphids and the highest number of syrphid larvae was noticed during the peak occurrence of aphids (Fig. 1). Jankowska (2005) also found that the first appearance of syrphid larvae in Brevicoryne brassicae crop grown at Agricultural Experimental Station in Mydlniki near Cracow (Poland) is about two weeks after appearing of aphids. A significant correlation coefficient 
$(0.83)\left(\mathrm{R}^{2}=68.9 \%\right)$ between the mean number of cabbage aphids and syrphid larvae was noticed. The regression equation is:

Total number of hoverfly larvae $(\mathrm{Y})=+0.668$ mean number of aphids $(\mathrm{X})-6.21$

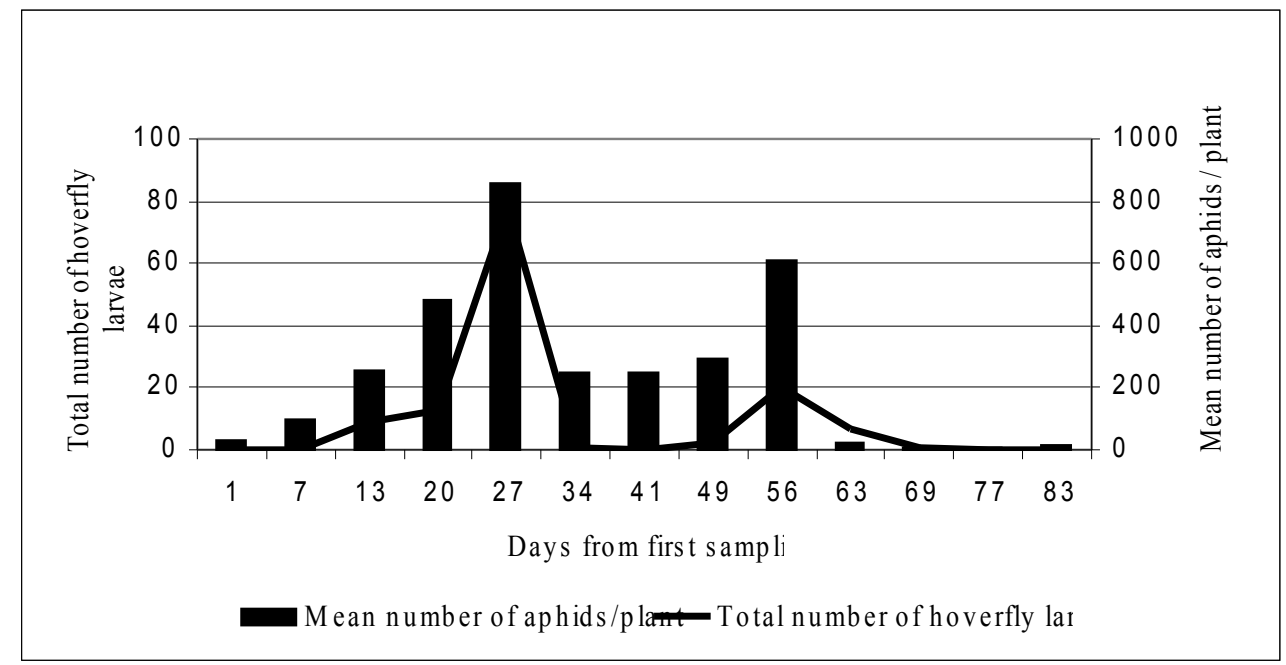

\section{Fig. 1. Population dynamics of hoverfly larvae with aphids on cabbage at Peradeniya}

Variance of the aphid populations on cabbage was higher than their respective mean values and showed that they were over dispersed (Table 1). The over dispersion of aphids in cabbage may be due to its colonizing behavior and high multiplication through parthenogenesis.

According to Table 1, variance of the hoverfly larval population was nearly similar to the respective mean values (except on one occasion) and showed that they were randomly dispersed.

\section{Occurrence of predatory syrphids in conventionally grown cabbage}

During the observation period, 41 syrphid larvae and pupae were collected. Out of them, thirteen adults of syrphids emerged and were identified as Allograpta javania and Episyrphus viridaureus. Most larvae died during rearing and $10.37 \%$ of the remaining ones was parasitized.

The average aphid population per plant had been decreasing drastically over 21-27 days from sampling (Fig. 2) and increasing thereafter. This may be due to the spraying of insecticides to the field on 08.02. 2009, 20 days after first sampling. The hoverfly larval population also decreased after the insecticidal spray over the rest of the sampling period (Fig. 2). Larval / pupal mortality of hoverflies in laboratory rearing was higher in samples collected in conventional fields compared to the samples collected in fields with no insecticidal spray. Correlation between aphid and syrphid larval populations was found to be less than 0.5 $(\mathrm{r}=0.235)$. 
Table 1. Estimate of different statistical parameters for the distribution of aphids and hoverfly larvae on organically grown cabbage of Peradeniya vegetable field

\begin{tabular}{|c|c|c|c|c|c|c|}
\hline \multicolumn{4}{|c|}{$\begin{array}{l}\text { Statistical parameters for the distribution of } \\
\text { aphids }\end{array}$} & \multicolumn{3}{|c|}{$\begin{array}{l}\text { Statistical parameters for the } \\
\text { distribution of hoverfly larvae }\end{array}$} \\
\hline $\begin{array}{l}\text { Days } \\
\text { from first } \\
\text { sampling }\end{array}$ & $\begin{array}{c}\text { Mean aphids } \\
\text { number/ } \\
\text { plant }\end{array}$ & Variance & $\begin{array}{c}\text { Variance : } \\
\text { Mean } \\
\text { ratio }\end{array}$ & $\begin{array}{c}\text { Mean number } \\
\text { of hoverfly } \\
\text { larvae/plant }\end{array}$ & Variance & $\begin{array}{l}\text { Variance : } \\
\text { Mean ratio }\end{array}$ \\
\hline 1 & 30.00 & 775.00 & 25.83 & 0.00 & 0.00 & - \\
\hline 7 & 100.00 & 2127.00 & 21.27 & 0.00 & 0.00 & - \\
\hline 13 & 258.33 & 14550.33 & 56.32 & 0.22 & 0.33 & 1.48 \\
\hline 20 & 478.33 & 218129.33 & 456.02 & 0.32 & 0.33 & 1.00 \\
\hline 27 & 854.33 & 9796.33 & 11.47 & 1.95 & 7.18 & 3.68 \\
\hline 34 & 247.33 & 5440.33 & 22.00 & 0.02 & 0.02 & 1.00 \\
\hline 41 & 247.33 & 109065.33 & 440.97 & 0.00 & 0.00 & - \\
\hline 49 & 296.67 & 15864.33 & 53.47 & 0.05 & 0.05 & 0.97 \\
\hline 56 & 607.67 & 282358.33 & 464.66 & 0.50 & 1.23 & 2.46 \\
\hline 63 & 20.67 & 357.33 & 17.29 & 0.18 & 0.25 & 1.43 \\
\hline 69 & 8.33 & 82.33 & 9.88 & 0.02 & 0.02 & 1.00 \\
\hline 77 & 4.33 & 24.33 & 5.62 & 0.00 & 0.00 & - \\
\hline 83 & 16.33 & 224.33 & 13.73 & 0.00 & 0.00 & - \\
\hline
\end{tabular}

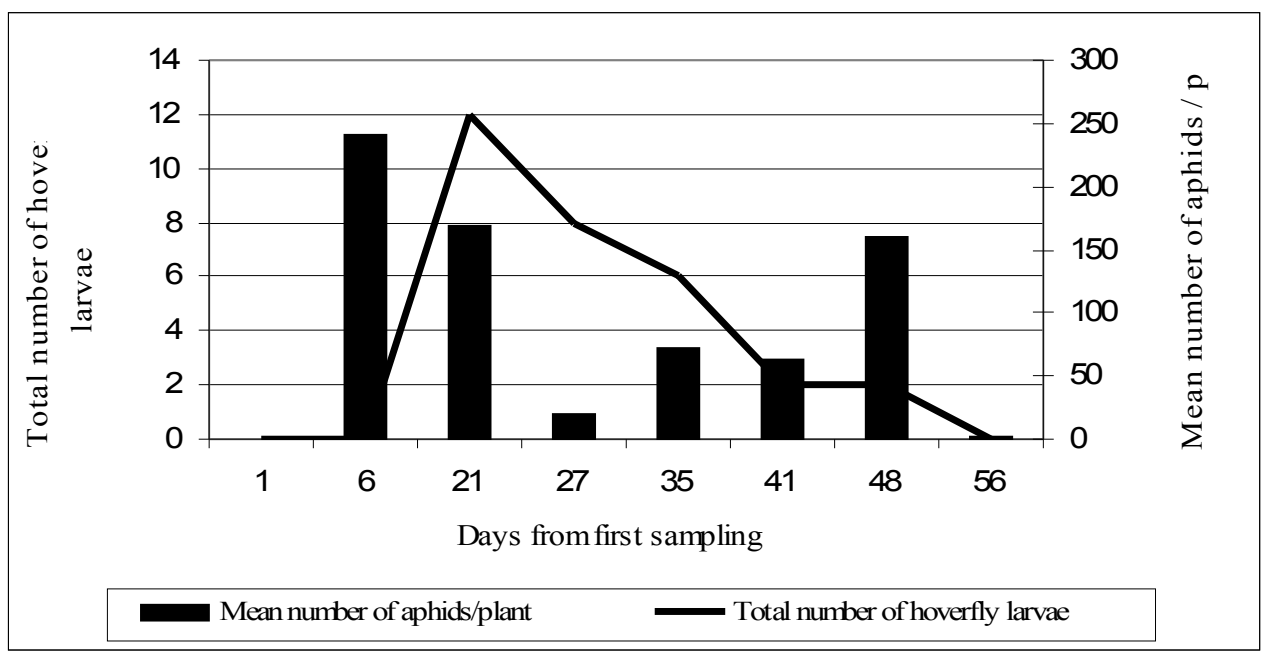

Fig. 2. Population dynamics of hoverfly larvae with aphids at conventional cabbage field

It is evident from the Table 2 that the variance of the aphid populations on cabbage was higher than their respective mean values and showed that they were over dispersed. The over dispersion of aphids in cabbage may be due to its colonizing behavior and high multiplication through parthenogenesis. 
As shown in Table 2, variance of the hoverfly larval population was nearly similar to respective mean values and showed that they were randomly dispersed.

Table 2. Estimate of different statistical parameters for the distribution of aphids and hoverfly larvae on organically grown cabbage of Paingamuwa vegetable field

\begin{tabular}{|c|c|c|c|c|c|c|}
\hline \multicolumn{4}{|c|}{$\begin{array}{c}\text { Statistical parameters for the distribution of } \\
\text { aphids }\end{array}$} & \multicolumn{3}{|c|}{$\begin{array}{l}\text { Statistical parameters for the } \\
\text { distribution of hoverfly larvae }\end{array}$} \\
\hline $\begin{array}{l}\text { Days } \\
\text { from first } \\
\text { sampling }\end{array}$ & $\begin{array}{l}\text { Mean number } \\
\text { of } \\
\text { aphids/plant }\end{array}$ & Variance & $\begin{array}{l}\text { Variance: } \\
\text { mean ratio }\end{array}$ & $\begin{array}{c}\text { Mean number } \\
\text { of hoverfly } \\
\text { larvae/plant }\end{array}$ & Variance & $\begin{array}{l}\text { Variance : } \\
\text { mean ratio }\end{array}$ \\
\hline 1 & 241 & 73936.33 & 306.79 & 0.00 & 0.00 & - \\
\hline 6 & 169 & 58887 & 348.44 & 0.30 & 0.27 & 0.90 \\
\hline 21 & 20 & 506.33 & 25.32 & 0.20 & 0.15 & 0.75 \\
\hline 27 & 72 & 9067 & 125.93 & 0.35 & 0.34 & 0.97 \\
\hline 35 & 63 & 11349 & 180.14 & 0.05 & 0.05 & 1.00 \\
\hline 41 & 159 & 28189 & 177.29 & 0.05 & 0.05 & 1.00 \\
\hline 48 & 1 & 1.333 & 1.33 & 0.00 & 0.00 & - \\
\hline 56 & 16.33 & 224.33 & 13.73 & 0.00 & 0.00 & - \\
\hline
\end{tabular}

\section{Comparison of two fields}

At a similar sampling effort, total number of hoverfly larvae in the insecticide free vegetable field (131) was four times higher than the conventionally managed field (30). From the adult syrphids that emerged (from both collected syrphid larvae and pupae) $84.6 \%$ was Allograpta javania while the rest was Episyrphus viridaureus in the conventional site. The situation is similar in the insecticide free field, which had $73 \%$ of Allograpta javania and $27 \%$ of Episyrphus viridaureus. According to observations, it can be concluded that the population of Allograpta javania is comparatively high in the cabbage growing areas.

In case of more than one hoverfly larvae collected from a plant, only one kind of hoverfly adults emerged. Parasitism of syrphid larvae was higher in the organic farm field. It was observed that $12.5 \%$ of the syrphid larvae collected from the Peradeniya field were parasitized whereas only $10.34 \%$ of larvae collected from the conventional field were parasitized.

\section{Parasitoids of hoverfly larvae in organically grown cabbage}

Out of the parasitized larvae, two species of Ichneumonid parasitoids of predatory hoverflies namely, Diplazon laetatorius (F.) and Diplazon orientalis (Cameron) and one species of Encyrtid belonging to genus Syrphophagous (Hymenoptera) were identified. The Diplazon laetatorius is a new record from Sri Lanka. A significant correlation coefficient (0.91) between total hoverfly larvae and the parasitized hoverfly larvae was noticed.

The largest group of reared parasitoids belonged to the family Ichneumonidae of which the most frequent one was Diplazon laetatorius reared from syrphid larvae. Per cent parasitism 
of hoverfly larvae by Diplazon laetatorius and Diplazon orientalis were 50 and 42.3 respectively. The species in this subfamily Diplazontinae are endoparasitic in Syrphidae. They oviposit in the egg or young larva of the host and emerge from the puparium (Broad, 2006). Schneider (1950), Dusek et al., (1979), Rotheray (1981), Wnuk (1974), and Wojciechowicz-Żytko (2000) noted that the commonest syrphid parasitoids belonged to the subfamily Diplazontinae. Diplazon laetatorius was the most important natural enemy of aphidophagous syrphid flies, in terms of abundance, in crops and pastures in Argentina (Greco, 1997).

In Sri Lanka, Diplazon orientalis has been bred from syrphid larvae feeding on the tea aphids (Cameron, 1905; Morley, 1913). Members of genus Diplazon are well-known and koinobiont endoparasitoids of predatory syrphids. The individual species are not normally host-specific. Female adults of Diplazon laetatorius begin to oviposit in 1st and 2nd instar syrphid larvae immediately after leaving the host puparium (Schneider, 1950).

The family Encyrtidae was represented by Syrphophagus sp. From one syrphid pupa, 29 larvae of parasitoid were hatched. The parasitism of pupae by Syrphophagus sp. was $6.3 \%$.

At the beginning of observations, the number of the parasitized larvae was low. As the number of syrphid larvae feeding in cabbage aphid colonies was increasing, the percentage of parasitized larvae also increased. The majority of infested syrphid larvae were found in July.

According to Wnuk (1974) and Wnuk and Wojciechowicz (1993) the parasitization has no influence on feeding capacity of syrphid larvae, but parasitoids play a negative role in limiting the future populations of Syrphidae.

\section{Morphological characters of identified hoverfly parasitoid species}

\section{Diplazon orientalis (Cameron)}

Length $6 \mathrm{~mm}$, abdomen black and segments are apically banded (Fig. 3). Apices of basal three segments of the abdomen narrowly lined with pale yellow. The apical lines interrupted in the middle. Mandible with upper tooth divided, thus appearing tridentate (Fig. 5), first metasomal tergite often square, fore tibia without apical tooth, areolet absent, propodium with strong carinae, ovipositor short. Wings hyaline, with the stigma and nervures black. Two m-cu cross veins, coastal cell absent (Fig. 6).

\section{Diplazon laetatorius (F.)}

Length 6.5 to $7 \mathrm{~mm}$. Abdomen brown and segments not apically banded (Fig. 4). Hind tibia tri coloured (basally black and black beyond the white central band, with the apex reddish brown). Mandible with upper tooth divided, thus appearing tridentate (Fig. 5), first metasomal tergite often square, fore tibia without apical tooth, areolet absent, propodium with strong carinae, ovipositor short. Wings hyaline, with the stigma and nervures black. Two m-cu cross veins, coastal cell absent (Fig. 6). 


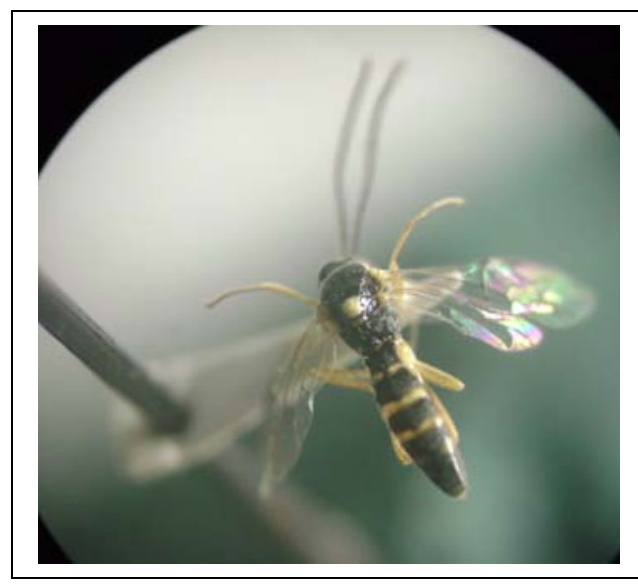

Fig. 3. Diplazon orientalis (Cameron)

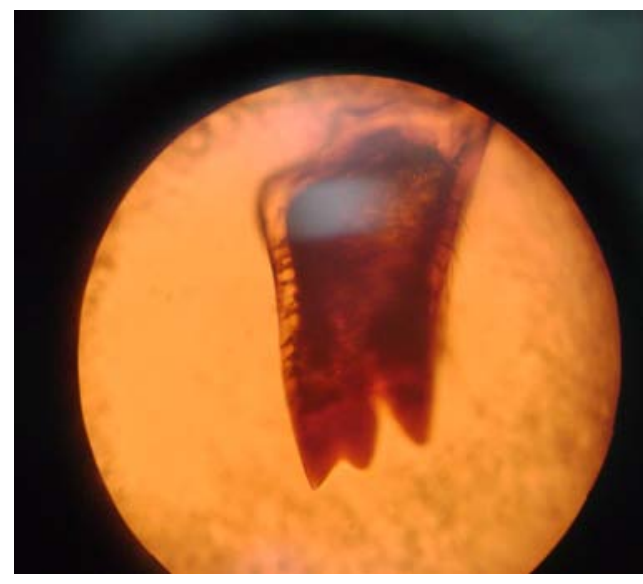

Fig. 5. Mandible of Diplazon spp.

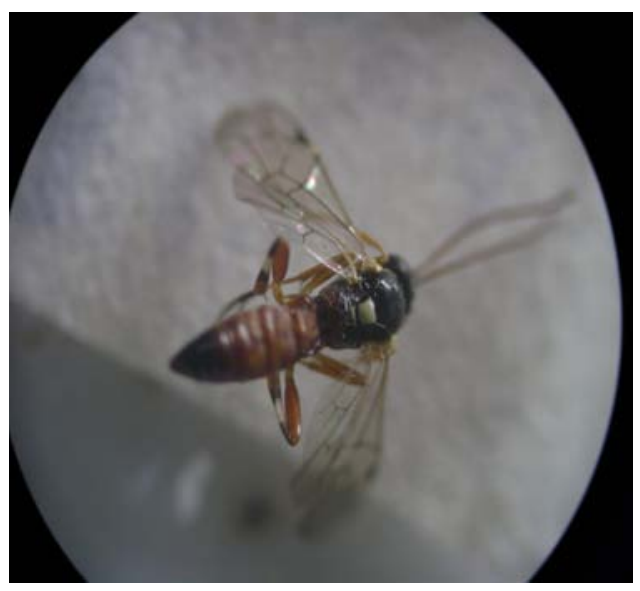

Fig. 4. Diplazon laetatorius (F.)

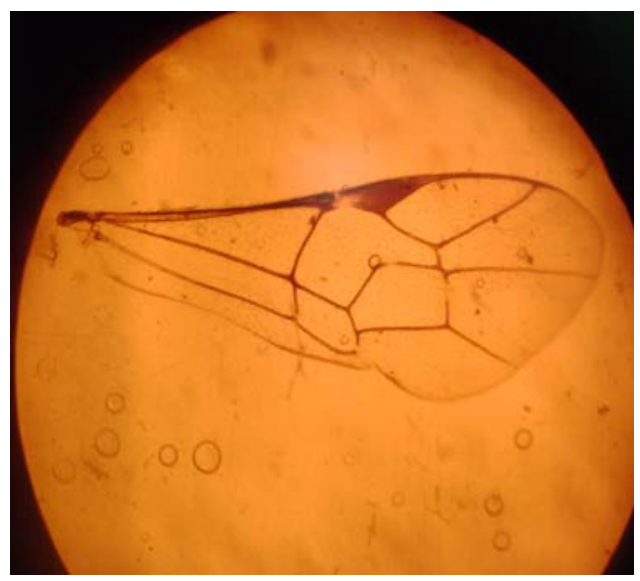

Fig. 6. Forewing of Diplazon spp.

\section{Syrphophagus sp.}

Body dark with metallic reflections; maxillary palpi and labial palpi four and three segmented; antennae (Fig. 7) inserted near oral margin; Scape (sc) long and cylindrical, pedicel (p) longer than first funicle (f) segment; funicle six segmented, club (c) three segmented; forewings (Fig. 8) with speculum (s) open; abdomen usually shorter than thorax; ovipositor hidden. 


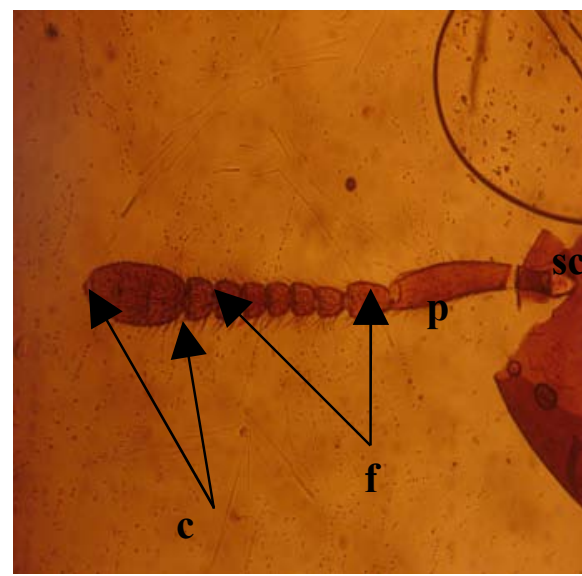

Fig. 7. Antennae of Syrphophagus sp

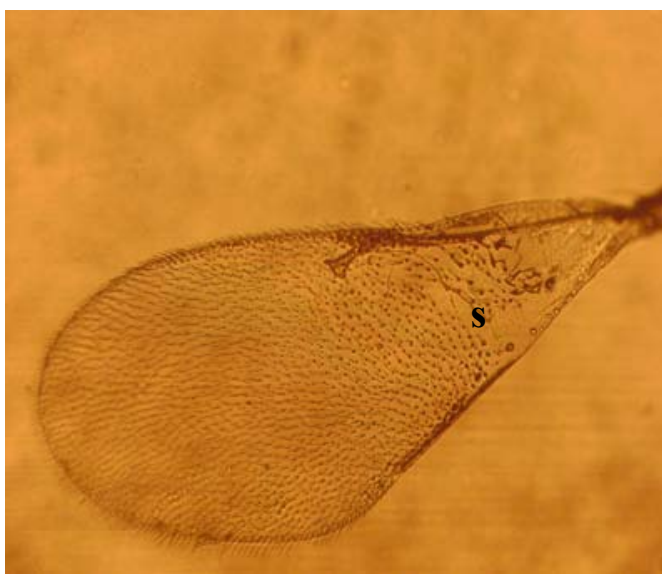

Fig. 8. Forewing of Syrphophagus sp

\section{Other natural enemies}

Predators of aphids other than syrphids were found at both sites, although usually in low numbers. Other natural enemies recovered from the two sites included ladybird beetles (Coccinelidae) and brown lacewings (Micromus sp.) (Hemerobiidae). This may be associated with negative impacts of hoverfly larvae. According to Hindayana et al., (2001), hoverfly larvae are vulnerable to intraguild predation since the larvae have low mobility. This suggests that predatory hoverflies might prefer to lay eggs at sites with few predators (Gilbert, 2005).

\section{CONCLUSIONS}

Total number of hoverfly larvae in the insecticide free vegetable field was more than four times higher than the conventionally managed field. Two species of predator hoverflies namely, Allograpta javania and Episyrphus viridaureus were identified from both fields. Allograpta javania was the dominant predatory hoverfly species in both fields.

Three species of parasitoids of predatory Syrphids were identified as Diplazon laetatorius (F.), Diplazon orientalis (Cameron) (Hymenoptera: Ichneumonidae) and Syrphophagus spp. (Hymenoptera: Encyrtidae). The Diplazon laetatorius is found to be a new record from Sri Lanka.

The most frequently found parasitoid was Diplazon laetatorius and the per cent parasitism was 50. The per cent parasitism of Diplazon orientalis was 42.3 and Syrphophagus sp. was 6.3 .

A significant correlation coefficient (0.91) between total hoverfly larvae and the parasitized hoverfly larvae was noticed. It indicates that the parasitoids play a role in limiting the future populations of Syrphids. At the beginning of observation period, the number of the parasitized larvae was low. As the number of syrphid larvae feeding in cabbage aphid colonies was increasing, the percentage of parasitized larvae also increased. 


\section{ACKNOWELEDGEMENT}

The authors wish to acknowledge the Council for Agricultural Research Policy of Sri Lanka for financial support (Grant No: 12/616/464) to conduct this study and Dr. Kumar Ghorpade, University of Agricultural Sciences, Krishi Nagar, Dharwar, India for the identification and confirmation of insect specimens.

\section{REFERENCES}

Baltazar, C.R. (1964). The genera of parasitic hymenoptera in the Philippines. Pacific Insects 6(1): 15-67.

Beibienko, G.Y. (1988). Keys to the insects of the European part of the USSR. V, Diptera and Siphonaptera, Part Two. The National Science Foundation, Washington, D.C. 11-148.

Borror, D.J., Triplehorn, C.A., Johnson, N.F.(1989). An introduction to the study of insects. $6^{\text {th }}$ Edition. Saunder College Publishing Company, Philadelphia. 518pp.

Broad, G. (2006). Identification key to the subfamilies of Ichneumonidae (Hymenoptera). Biological Records centre, CEH Monks Wood. 1-38.

Cameron, P. (1905). On the phytophagous and parasitic hymenoptera collected by Mr. E. Ernest Green in Ceylon. Spolia Zeylanica 3: 67-143.

Chambers, R.J., Sunderland, K.D., Stacey D.L. and Wyatt, I.J. (1986). Control of cereal aphids in winter wheat by natural enemies: aphid-specific predators, parasitoids and pathogenic fungi. J. Appl. Biol. 108: 219-231.

Dusek J., Laska P. and Sedivy J. (1979). Parasitization of aphidophagous Syrphidae by Ichneumonidae in the Palearctic Region. Acta Ent. Bohemoslov. 76: 336-378.

Emden, V.H.F., Eastop, V.F., Hughes, R.D. and Way, M.J. (1969). The ecology of Myzus persicae. Ann. Rev. Entomol. 14: 197-270.

Daniel, A. S. and Drew, W.A. (1976). Syrphidae of Oklahoma (Diptera). Proc. Okla. Acad. Sci. 56: 75-94.

De Silva, D.M. (1961). A preliminary list of the native parasites and predators of insect pests in Ceylon. Trop. Agric. Res. (CXVII): 115-141.

Ghorpade, (1994). Diagnostic keys to new and known genera and species of Indian Subcontinent, Syrphini (Diptera: Syrphidae). Colemania: Insect Biosystematics. No 3: 1-15.

Gilbert, F.S. (2005) Syrphid aphidophagous predators in a food-web context. Eur. J. Entomol. 102: 325-333.

Greco, C.E. (1997). Specificity and instar preference of Diplazon laetatorius (Hymenoptera: Ichneumonidae) parasitizing aphidophagous syrphids (Diptera Syrphidae). Entomophaga 42(3): 315-318.

Hindayana, D., MeyhÖfer, R., Scholz, D and Poehling, H.M. (2001). Intraguild predation among the hoverfly Episyrphus balteatus de Geer (Diptera: Syrphidae) and other aphidophagous predators. Biol. Cont. 20: 236-246. 
Jankowska, B. (2004). Parasitoids of aphidophagous syrphidae occurring in cabbage aphid (Brevicoryne brassicae L.) colonies on different cabbage vegetables. J. Plant Prot. Res. 44(4): 299-305.

Jankowska, B. (2005). Predatory syrphids (Diptera, Syrphidae) occurring in the cabbage aphid (Brevicoryne brassicae L.) colonies on different cabbage vegetables. J. Plant Prot. Res. 45(1): 9-16.

Morley, C. (1913). Fauna of British India. Hymenoptera 3. Ichneumonidae 1. Taylor and Francis, UK. pp 280-281.

Rotheray G.E. (1981). Host searching and oviposition behaviour of some a parasitoids of aphidophagous Syrphidae. Ecol. Entomol. 6(1): 79-87.

Schneider, F. (1969). The development of the syrphid parasitoid Diplazon fissorius Grav. in uni-, oligo-, and polyvoltine hosts, and its behaviour during activation of the diapause larvae using D. pectoratorius Grav. Mitt. Schweiz. Ent. Ges. 23: 155-194.

Scott, E. I. (1939). An account of the developmental stages of some aphidophagous Syrphidae and their parasites. Ann. Appl. Biol. 26: 509-523.

Shukla, R.P. (1990). Spatial distribution of key pests of mustard and their natural enemies in India. Trop. Pest Management 36(2): 85-88.

Sobota, G. and Twardowski, J. (2004). Variation in species spectrum of hoverflies (Diptera: Syrphidae) in arable crops depending on the collection method. Electronic Journal of Polish Agricultural Universities. 7(2): 8.

Vockeroth, J.R. and Thompson, F.C. (1987). Syrphidae. pp. 713-743. In: McAlpine, J.F. (Ed.). Manual of Nearctic Diptera, 2. Research Branch, Agriculture Canada, Monograph. No. 28.

Wnuk, A. (1971). Bzygowate (Syrphidae: Diptera),drapieżcy mszycy kapuścianej

Brevicoryne brassicae (L.) (Homoptera: Aphididae). Zesz. Nauk. WSR w Krakowie nr. 62

Rolnictwo. 13: 45-53.

Wnuk A., Fusch R. (1977). Obserwacje and efektywnością ograniczania liczebności mszycy kapuścianej Brevicoryne brassicae (L.) przez bzygowate (Diptera, Syrphidae). Pol. Pismo Entomol. 47: 147-155.

Wnuk A., Wojciechowicz E. (1993). Drapieżne bzygowate (Diptera, Syrphidae) występujące wkoloniach mszycy kapuścianej Brevicoryne brassicae (L.) na kapuście i kalafiorze. Pol. Pismo Ent. 62: 215-229.

Wojciechowicz-Żytko E. (2000). Diplazon laetatorius (Hymenoptera, Ichneumonidae) as a parasitoid of aphidophagous Syrphidae (Diptera). Proceedings of the $\mathrm{XV}^{\text {th }}$ Czech and Slovak Plant Protection Conference in Brno. September 12-14: 447-448.

Weems, H.V. (1953). The syrphid flies of Southwestern United States. Unpublished Ph.D thesis., Ohio University, Ohio, USA. 